\title{
Reduction and Management of Waste in Hotel Industries
}

\author{
Vikas Mohan ${ }^{1}$, Bansal Deepak $^{2,3}$, Sharma Mona $^{4} *$ \\ ${ }^{1}$ Department Of Tourism And Hotel Management, Central University Of Haryana, Mahendergarh, Haryana, India \\ ${ }^{2}$ JBM Group, Gurgaon \\ ${ }^{3}$ Department Of Environmental Science \& Engineering, Guru Jambheshwar University Of Science \& Technology, \\ Hisar, Haryana, India \\ ${ }^{* 4}$ Department Of Environmental Sciences, Central University Of Haryana, Mahendergarh, Haryana, India
}

\begin{abstract}
The present review article is trying to compile the available information from literature on reduction and management of waste in the hotel industries. As per the available literature, 5 Rs Transition Strategy is good for managing the waste of motels and hotels industries. This paper also covered the various issues like need of waste management, importance of waste management, nonhazardous waste and methods of waste decompose. Now a day, hotels are investigating the requirement of waste reduction and are trying to implement those alternative and new practices which can cut their waste disposal cost, protect and conserve our environment and also increasing loyalty of guests.
\end{abstract}

Keywords: Hotel industries, waste reduction; transition strategy; environment.

\section{INTRODUCTION}

In the present era, hotel industries are analyzing the need of waste reduction and they are emphasizing to implement various new practices which can cut their waste disposal cost, protect and conserve nature and also increasing loyalty of guests (Georgia Hospitality Environmental Partnership Report, 1996). As the load of the waste increased and put more in the ground, then landfills produce and release methane gas $\left(\mathrm{CH}_{4}\right)$ which is a contributor for causing greenhouse effect (Abu-Khader, 2006) and play an important role for global warming and increasing the carbon footprint (Deepak et al., 2017). Landfills also produce leachate (a toxic sludge) which can kill our flora and fauna through water contamination (Georgia Hospitality Environmental Partnership Report, 1996).

Particularly, waste causes environmental pollution and contributes to global warming which ultimately leads to climate change and depletes energy, water and natural resources (Mona et al., 2011). Environmental Management System (EMS 14001) can play a major role in managing the waste generated from different industries (Bansal et al., 2015). By making a small change in day to day life then we can make a powerful difference to the environment and health of all living beings.

In the present era of industrialization, owners and operators of the hotels are investigating different ways to decrease the amount of waste generated during operations, so that the cost of disposal, energy and water recourses can be efficiently utilized for sustainable manufacturing. This would increase the number of loyalty guests and protect the environment. Few proactive hotel industries have mandated hotel environmental programs for the conservation of water and energy efficiently and can helpful in waste reduction and recycling. For an example, the Georgia hospitality industry has always been keen and deeply concerned about the environment. Today, industrial leaders evaluate their environmental and green practices including reduction and recycling of waste. Initially, the industry was satisfied to manage and organize an efficient system of waste removal, but, now they are more concerned about changing various methods, practices and costsof waste disposal. Disposal of solid waste must be examined regularly due to intensifying costs associatedwith landfills and it can also be increasing opportunities to recycle the waste.

Many laws and regulations are formed for the disposal of business waste in hotel industries. Georgia following the Comprehensive Solid Waste Management Act and having goal to reduce $25 \%$ waste per capita by 1998 (Georgia Hospitality Environmental Partnership Report, 1996). This goalof Georgia implies responsibility of an individual but also includes various businesses and industries like (hotels and restaurants).The landfill space is becoming increasingly expensive due to new laws and regulations and very 
fewer are being built. Therefore, for sustainable manufacturing in the hotel industries, the practices must be improved for handling the waste (Malik and Kumar, 2012). The present review paper on reduction of waste in the hotel industries is trying to compile all relevant information available in literature for reducing and recycling the waste generated during manufacturing and disposal in the hotels.

\section{WASTE MANAGEMENT IN HOTELS}

A Practical way for waste management is the 5R Transition Strategy (https:/ perma culturesocietyph. wordpress.com/ introduction-topermaculture/what-is-permaculture/5r-transition-

strategy/). These 5Rs allow a clear departure from the consumer end and start an eco-friendly way of life to save the nature. The best way to improve waste management is to follow 5 Rs for saving the environment. These five Rs are (Table 1):

Table 1: The 5Rs Transition Strategy

\begin{tabular}{|l|l|l|}
\hline $\begin{array}{l}\text { Sl. } \\
\text { No. }\end{array}$ & 5Rs & Remark \\
\hline 1. & Refuse & $\begin{array}{l}\text { Try to end the utilization of disposable items and } \\
\text { toxin generating services/goods }\end{array}$ \\
\hline 2. & Reduce & $\begin{array}{l}\text { Try to limit their ecological footprint and the best } \\
\text { way to improve waste management is to create as } \\
\text { little waste as possible }\end{array}$ \\
\hline 3. & Reuse & $\begin{array}{l}\text { Try to choose those items which can be usable } \\
\text { again and again and need to set up systems to } \\
\text { collect and sort the waste so that it can be reused }\end{array}$ \\
\hline 4. & Recycle & $\begin{array}{l}\text { Try to recycle the conventional sources before } \\
\text { throwing away. There are many hotels, motels, } \\
\text { restaurants and tourism places which already } \\
\text { established some system in place for sorting and } \\
\text { collecting everyday waste like cans, bottles, } \\
\text { paper, cardboard, etc. for reuse/recycling. }\end{array}$ \\
\hline 5. & Restore & \begin{tabular}{l} 
Try to restore goods for the other services. \\
\hline
\end{tabular}
\end{tabular}

\section{NEED OF WASTE MANAGEMENT IN HOTEL INDUSTRIES}

Waste management programme would helpin reducing the level of waste generation and increase efficient utilization of materials, energy and water resources. In hotels, owners often pay twice for the waste; firstly in the form of packagingand secondly for their disposal.On an average, a hotel generates approximately $1 \mathrm{~kg}$ of waste per night per guest (International Tourism Partnership Report, 2008). Therefore, disposal of waste of a year is costly and required a lot of money due to diminishinglandfill capacity and high cost of waste collection. Waste rules and regulation on households and business is becoming very stringent, especially in the European Union countries (International Tourism Partnership Report, 2008).

Many stuffs/items of waste are also valuable in nature, can be recycled into other items.Hotel owners may be made money from their generated wastes.
Around $30 \%$ of a hotel's solid waste can be sorted, reused, recycled and recoverable in nature (International Tourism Partnership Report, 2008). Therefore, it's a need of an hour to manage the waste of a hotel industry for protecting and conserving natural resources and the environment.For small scale hoteliers, there are three major options are available for assessing the solid waste generating in the business (Remolador, 2011):

\section{Step 1: Self-evaluationfor Waste Management Practices}

First most important step is self-evaluation of the waste may be done at any time without need for outside help. This step involves critical manual checking at all the areas of a hotel, producing waste. At this level a step can be taken for efficiently utilization of waste. A checklist can also be prepared for selfevaluation of the waste. Tools like the Environmental Walkthrough can also be developed especially for small scale hotels in order to provide exact and useful information regarding the savingof water, energy and other useful materials. Another tool is small hotel environmental assessment which involves a team work having two trained experts analyzing the whole situation property within two-three days. The specialized team reviews all the facilities, operation procedures, baseline performance and prepare a comprehensive list of best alternative practices. The team also delivers a report and mentioned the best practices and opportunities for reducing, restore, recycling and reusing waste and also provides a list of guidelines on implementation.

\section{Step 2: Fix their priorities and take immediate} action

After self-evaluation and identification of opportunities or alternative practices for improving waste management in a hotel, try to set their priorities and implement most attractive measures by following the schedule and action plan with assigned responsibilities and also sets target dates. There are few guidelines for managing waste in the priority orders are:

(i) Reduction of waste at the source point: First option for managing the waste is reducing the generation of waste is the first option that should be considered. This approach promotes the efficient use of resources and reduces the volume of waste material that must be handled by employees and hauled away from the property. Responsibility for reducing waste generation generally lies with management, who decides what is brought into the property and, thereby, determines what eventually leaves the property as waste. 
(ii) Reuse: Items in hotels, whenever is possible should reuse in their original form or check can this item may be used for different purpose before discarding the same. If stuff cannot be reusable at site, then their property should be investigated for another use.

(iii) Recycle: Third important task is recycling of the product which consists of handling and transforming the waste into novel and marketable products. But, this method is least favorable out of the three waste management strategies and considered only when reduce and reuse options are not applicable for a particular waste streams. This method is most difficult to implement for waste management.

Step 3: Continuous improvements and investments:

This can be used by following the low cost practices in solid waste management. Try to reduce unnecessary waste generating in the hotel industries.Hotel industries can save their huge amount of money by purchasing reusable products rather than disposables. It is possible that sometimes initial cost is high for reusable products, but, it offers substantial savings over a longperiod of time. For example try to use cloth cleaning rags instead of paper towels or disposable J-cloths and paper napkins can be replaced by table coverings with linen. Cloth bags or wheeled bins can also be used for collection of yard waste instead of plastic bags.

\section{BENEFITS OF WASTE REDUCTION IN HOTEL INDUSTRIES}

First most important benefit of waste reduction is money savings by reducing purchasing costs, waste disposal costs,energy consumption and environmental pollution.Second important benefit is conservation of natural resources.Reuse, reduce, recycling are three processes by which hotel waste can be managed. Recycling is one of the key factor which prevents usefulmaterials from being combusted and landfilled, and thusalso saving energy and other natural resources (Malik and Kumar, 2012).

\section{Three major steps for recycling are:}

1) Collection of solidwaste

2) Processing and manufacturing of the products intoreusable products

3) Purchasing of the products which are made up of reprocessed materials, and can be reutilized.

Recycling programs for hotels are focusing on collection of recyclable materials from waste stream of different areas of the hotel.

\section{NONHAZARDOUS WASTE MANAGEMENT}

Before boarding on a waste-segregation programme, first find out which type of material can be collected from local waste and recycling contractors. In many countries, recycling and waste management programmes are relatively well advanced; there waste may be separated into various categories. Implement recycling actions for items wherever practically possible. Sometimes, local conditions may inhibit the many actions of recycling. For an example, many countries lacking infrastructure for recyclable elements coming from waste streamslike plastic bottles. Try to reduce or eliminate the waste. It's better to minimize the waste at the point of source such as: avoid the utilization of plastic straws, use containers having lids, use refillable soap containers, use reusable glass bottles, cleaners and foodstuffs, use canvas bags and cloth or baskets for laundry purposes, shoe polish, etc. instead of plasticbags. Try to make the compost using biodegradable or organic waste generated in the hotel kitchens.

\section{COMPOSTING}

Composting is one of the natural decomposition methods for organic materials, for yard waste and vegetables and fruit waste, compost may be made by ubiquitously available microorganisms (Mona et al., 2016). This is a simple process and requires some modest amount of efforts and can significantly reduce the amount of solid waste and also eliminate the need of fertilizer or mulchpurchasing.

First key step in composting is a separation of waste on the basis of compostable materials (such as yard waste, fruit peels, vegetable cuttings). The noncompostable waste like plastics, metals, meat and fatty food waste, metals etc. as they are generated in the hotels (Sharma et al., 2013). Concerned persons can also separate the wastes from the beginning. There are a number of methods available for composting, simply from "no-tech" methods, to windrow methods for accelerating the composting. Actually, the simpler procedure is economic but, slower in nature, while the other engineered procedures are faster and requires less space, and can be more affordable by controlling risks of odors. This compost can be utilized in the garden area of the hotels for maintaining the fertility of the soil. Composting and vermin-composting (composting through worms) are two efficient methods for decreasing the load of solid waste generated from hotels (Saud, 2013). 


\section{CONCLUSION}

The steps outlined in the present article on the basis of literature reviewed are not difficult and can be fulfilled by the hotel industries for managing their waste. But, the hotels do require a commitment of the management and staff to manage their waste they spare time for implementing the waste management strategies. If a hotel is green hotel, then the message should pass to all potential guests that the hotel management, staff, and corporation all believe that environment conservation and protection is an important factor during the hotel operations. This message can play a powerful role in getting guest loyalty and selling other guest services.

\section{REFERENCES}

[1]. Abu-Khader, M.M., 2006. Recent Progress in $\mathrm{CO}_{2}$ Capture/Sequestration: A Review. Energy Sources Part A 28, 1261-1279.

[2]. Bansal, D., Narsi R. Bishnoi, and Mona, S. 2015. Challenges and benefits of implementing an Environmental Management System: A review. International Journal of Advanced Scientific and Technical Research 5 (2), 159-180.

[3]. Deepak, B., Nidhi, Y., Munish, B., Bishnoi, N. R., *Mona, S. 2017. Energy Management Practices in an Autoancillery to Reduce Carbon Footprints for Environmentally Sustainable Manufacturing, International Journal of Engineering Research and Application 7(7): 20-25

[4]. Georgia Hospitality Environmental Partnership Report 1996.
[5]. https://permaculturesocietyph.wordpress.com/ introduction- to- permaculture/ what-ispermaculture / 5r-transition- strategy/

[6]. International Tourism Partnership Report 2008 on Environmental Management In Hotels

[7]. International Tourism Partnership Report, 2008 on Waste Reduction in Hotels and Motels.

[8]. Malik, S., Kumar, S 2012. Management of Hotel Waste: A Case Study of Small Hotels of Haryana State. Arth Prabandh: A Journal of Economics and Management 1(09) 43-55.

[9]. Mona, S., Kaushik, A. and Kaushik, C.P. 2011, Hydrogen Production and metal-dye bioremoval by a Nostoc linckia strain isolated from textile mill oxidation pond. Bioresource Technology (Elsevier) 102, 3200-3205 [IF: 5.039]

[10]. Remolador, M.A. 2011, Northeast Recycling Council Report on Guide to Greening Hotels through Waste Management \& Green Purchasing pp 01-08.

[11]. Saud, J.S., 2013. Solid waste management utilizing microbial consortia and its comparative effectiveness study with vermicomposting. International Journal of Engineering Research \& Technology (IJERT) 2(10), 2870-2885.

[12]. Sharma, A., Mishra, M., Sheet, S., Thite, M., 2013. Role of microbes as cleaning degrading industrial wastes for environmental sustainability- A Review. Recent Research in Science and Technology 5(5), 21-25.

International Journal of Engineering Research and Applications (IJERA) is UGC approved Journal with Sl. No. 4525, Journal no. 47088. Indexed in Cross Ref, Index Copernicus (ICV 80.82), NASA, Ads, Researcher Id Thomson Reuters, DOAJ.

Vikas Mohan. "Reduction and Management of Waste in Hotel Industries." International Journal of Engineering Research and Applications (IJERA) 7.7 (2017): 34-37. 